\title{
ISTANBUL AND THE CARPET TRADE OF IRAN IN THE NINETEENTH CENTURY
}

\author{
Tsutomu SAKAMOTO*
}

\section{Introduction}

Istanbul was not only the capital of the Ottoman Empire, but also largely contributed to the political, cultural and commercial development in the neighboring Islamic countries.

The Ottoman reform movements exerted great influence on many Iranian migrants or residents in Istanbul. For instance, Mīrza Hoseyn Khān Sepahsālār, one of the most famous politician, stayed there from 1858 to 1871 as Ambassador of Iranian Embassy. He was associated with a lot of Tanzimat reformists such as 'A $\bar{l}$ ì Paşa and Fuat Paşa at the time of his residence. After finishing his diplomatic service, he devoted his great energies to the task of modernization of Iran on the model of Tanzimat reform in the Ottoman Empire(1).

Some of Iranian constitutionalists, secular or not, also were affected by the contemporary Young Turk movement. $\bar{A}$ ghā Khān Kermānī contributed his many useful articles on constitutionalism to Persian newspaper Akhtar. His political idea was enlarged by his contact with prominent intellectuals and by knowing the Turkish progressive political ideas(2).

Taqĩzādeh and Doulatābādi were forced to migrate to Istanbul after the bombardment of Majlis in Tehran in 1908. Each one unexpectedly encountered the Young Turk Revolution. While they took refuge in Istanbul for a short time, they concentrated their efforts to reorganize their political parties on their ground each other( 3 ).

Pan-Islamism gave a little impact on Iranian intellectuals. Qajar prince Shaykh al-Ra'is supported Abdülhamit II's Pan-Islamic appeal, and so he wrote down a brief pamphlet, Ettehäd-e Esläm in Bombay(4).

We can see the inclination for the Pan-Islamic idea in Farāhānì's travel book to Mecca. He travelled to and from Mecca in 1885-86 by way of

* Professor, Keio University 
Istanbul. He had an opinion to oppose the constitutional system, and so gave a great support to the Abdülhamit II's autocratic system(5).

From the commercial point of view, Istanbul was indispensable for Iran during the Qajar Dynasty as international intermediate market between Europe and Iran. For example, Manchester cotton goods for export to Iran were first brought to Istanbul, where their wholesale dealings with Greek or Armenian big merchants of Istanbul were done, and then next they were reexported to Iran by the hands of Armenian or Azerbaijani traders who were regularly travelling to and from Istanbul(6).

On the other hand, main Iranian cash crops also, were not necessarily exported to European countries directly. Silk of Gilan was principal export goods from Iran until 1860s, and usually was conveyed to Milan and Marseilles markets by way of Istanbul.

Iranian tobacco for water pipe was more excellent in quality than that of any other Islamic countries. These products were regularly exported to such provinces as Turkey, Syria, Egypt and Hijaz. Tobacco, of course, was consumed in Istanbul in great quantity. However, Istanbul played a remarkable role as distribution centre to other provinces more than as consumption place. It is known that there were many Iranian tobacco traders in Istanbul at the time of the Tobacco protest movement in 1891-92(7).

Carpet export trade began to develop since 1870s after the decline of silk trade. Istanbul was one of the main exits of Iranian carpets for export to European countries and America up to the World War I. In this present paper the following problems are argued; 1 . the carpet trade of Tabriz after the decline of silk trade, 2 . the development of carpet production in Iran since $1870 \mathrm{~s}, 3$. Istanbul as the intermediate market for Iranian carpets.

Of the 19th century Iranian cities, Tabriz was the most prosperous city as a transit and a re-export center, where two main international trade routes intersected. One route is so-called Tabriz-Trabzon route which was opened at the end of $1820 \mathrm{~s}$. Many caravans passed along this route from Tabriz to Trabzon by way of Erzurum, and then at the port of Trabzon passengers and cargoes could pick up the steamship and reach Istanbul. From there onwards they could go anywhere in Europe. This route became the principal 
ISTANBUL AND THE CARPET TRADE OF IRAN IN THE NINETEENTH CENTURY

traffic road because of a short cut to Europe, along which export and import trades between Iran and European countries were largely carried out. In short, the formation of the world trade system in capitalism gave birth to this route( 8 ).

Another route was a branch of the so-called Transcaucasus route. It stretched north from Tabriz to Tiflis to join the overland route, traversing Transcaucasus province from Batum to Baku. This route became active after the Treaty of Torkomanchai in 1828. A progressive trade between Iran and Russia was carried out. Especially, after the government of Russia determined not to impose customs on foreign goods passing by this Transcaucasus route in 1865 , the traffic of this route and its branch continued to develop up to 1883 , when the policy of duty free on the imported goods was abandoned( 9 ).

Tabriz continued to play a major role in export and import trade owing to its location, but now we would like to confine our remarks only to the change in the main export goods from Tabriz.

Until 1860s, Silk stood first among export goods from Tabriz. Many wholesale dealers, foreigners or not, established their firms in Tabriz, and so continued their energetic commercial activities. We can give only the names of these firms such as Greek firm, Ralli \& Co. and British firm, Ziegler $\&$ Co.. Besides foreign companies, we can find the activities of some native merchants in the reports of British consuls, but regrettably concrete names are not known. wholesale dealers travelled to and from Gilan to collect silk, and distributed those silk for export abroad(10).

We can show a tendency of silk export trade from Tabriz at Table 1. According to this statistics, in 1864, the value of the amount of silk was $£ 502,000$ and highest of all years. In this year the value of the amount of silk reached the highest percentage of 83.7 of the total exports. On the other hand, three years later, in 1867 the value of the amount of silk greatly decreased to $£ 65,000$, accounting only $10.1 \%$ of the total exports. The figures shown in percentage was lowest of all fifteen years.

The diminution of silk exports was caused by silkworm disease occurred in 1864. The silk production suffered a crushing damage from this disease. Although many silkworm eggs were imported mainly from Japan after that time, neither silk production nor silk trade could be restored to an earlier condition. (11) 
Generally the balance of trade in Tabriz was the excess of imports over exports, and so Tabriz was suffering from huge deficit as the result of the drain of much Iranian money. The trade of Tabriz got worse more seriously by silkworm disease, and finally by the rapid diminution of silk exports.

In 1870s, as ever the situation of trade balance in Tabriz was not improved, rather than before it sustained further damage from the RussoTurkish war. British Consul General Abbott stated his own opinion about such a crisis in his report on the trade and commerce of Tabriz for the years $1877-78$ as follows.

"The excess of imports over exports, involving a continued drain of specie cutwards, threatens to produce most serious consequences; nor have the silk crops in Gilan contributed to remedy this state of things. The Caspian provinces appear to yield less silk every year: in 1876 the crops are reported to have been "worse than ever;" and when it is considered that the prosperity of the foreign commerce of this country mainly depends upon that of the silk trade, there being no other products of the kingdom suitable for exportation from this side, which furnish returns for one half of the merchandise annually imported from Europe, the conclusion to be arrived at is that Persia is drifting into bankruptcy, which the effects of the late war (=Russo-Turkish War), detailed above, must tend to acceler-

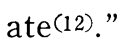

Regrettably, we cannot have detailed statistics on the export trade of Tabriz for 1872-1884. However, according to a fragmentary statistic of Table 2 , it appears that silk still occupied the first place among export goods in spite of its less value of the amount in 1870, 1872 and 1873.

But immediately after the great famine in Iran for 1870-71, new trend of export trade was towards the increasing of carpet trade. British Consul General Jones stated this tendency in 1872 as follows.

"This trade is, however, gradually attaining importance, the demand for Persian fabrics, in the shape of carpets, shawls, \& c., is increasing rapidly, notwithstanding the rise in the price of wool, caused by the mortality among the flocks during the late famine. Russia offers the chief market for these manufactures, but a considerable quantity is sent westward also(13)."

The Vienna exhibition in 1873 promoted the export trade of Iranian carpets. European people began to appreciate the commercial and artistic value of Iranian carpets represented there. Since then, Iranian carpets were 
winning popularity among European people. The government of Iran afforded every assistance to those wishing to send their merchandise to Vienna, and to remit the export duty on all goods destined for the exhibition. The Austrian Government and transport companies offered likewise considerable advantages to the Iranian exhibitors, allowing their merchandise to enter duty free, and to be transported by sea and land at very reduced rates(14).

According to Table 3, in 1878-79 carpets became at the top in export trade for the first time. Silk became lower to be the third place in the value of amount. Consul General Abbott stated this increasing carpet trade in his report for 1878-79 as follows.

"The only articles of export which gave hope of yielding a profit were the carpets of this country, which have acquired a great reputation throughout Europe. On the list of exports annexed to this report, carpets figure to the amount of 65,000l., whereas last year they formed the small item of 15,000 $l$. An agent from the Maison du Louvre at Paris is despatched annualy to Persia for their purchase; but besides being in fair demand in the principal markets of the European continent, they are now exported hence to the United States(15)."

In this way, since the second half of 1870 s, Iran could find a way out of export difficulties in carpet trade. From that time onwards foreign or native manufacturers started to organize carpet production in a great quantity at the various parts of Iran.

In Iran, from ancient times carpets were continuously woven anywhere wool, other materials and weavers were easily obtained. Those carpets were woven mainly for personal use, or for royal princes and nobilities in a limited form. However, as the demand for carpets from abroad considerably grew, remarkable places for carpet production appeared in the 19th century. British Consul General Jones and Consul General Abbott described in their reports as follows.

1) Persian Iraq area including Farahan, Soltanabad, Saraband.

2) Khorasan area, especially Mashhad.

3) Kurdistan, especially Senneh. 
4) Azerbaijan area including Bekshayish, Heriz, Qaradagh, especially Khanomrud.

5) Torkoman steppe.

Soltanabad was most important of these production places, because big carpet factories based upon modernized system were newly created in this town, and moreover in nearby areas a great number of manufacturers energetically weaved carpets by their hand looms. The carpet production of Soltanabad was completely different from the traditional small scale carpet production of other areas in many ways such as management, labor system and export trade.

Large scale carpet production at Soltanabad was started by British firm, Ziegler \& Co. around 1874. Originally this firm had headquarters in Manchester, and so as early as 1830 s opened a branch office at Tabriz. Its main business to do was export trade of Manchester cotton goods to Iran and import trade of Gilan silk to the British Empire(16).

However, in 1860s many foreign firms doing business in silk trade suffered huge damage from silkworm disease, so most companies withdrew from Iran with closing of their offices. One of these companies was a well known Greek firm, Ralli \& Co. which closed its Tabriz branch in 1871. But Ziegler \& Co. never imitated the activities of other firms, rather decided to find out new commercial goods for export on behalf of silk. Consequently, new woven factory was established at Soltanabad(17).

Now, unfortunately, detailed company records, documents and other historical materials relating to Ziegler \& Co. are not available. I myself investigated the documents at Public Record Office, Guild Hall Library and Manchester City Library a few years ago, but I could not find out any useful sources(18).

So I must confine myself to the consular report written by Consul General of Isfahan, J. R. Preece. He travelled around Yazd, Kerman, Shiraz, Soltanabad, Kashan and so on from October 24, 1893 to December 8, 1893. His report is very long and considerably useful for us, because he was interested in the economic condition of Iran, so he wrote down more detailed description on carpet trade and industry.

He stated the following remarks about carpet woven factory of Ziegler \& Co.. "Nearly 20 years ago, Messrs. Ziegler, of Manchester, who have 
representatives in Tabreez, Tehran, Ispahan \& c., finding that exports from Persia did not afford them sufficient means to return their capital to Manchester, looked about them for additional ways of exit for their money and conceived the idea of developing this carpet trade. M. Alpiger, one of their employees in Tabreez, was deputed to work the question up, and it is due to his quiet persistence and never falling courage that the trade has become the important one it is. With no assistance from Government and without any concession, but simply by good honest work and assiduity, in face of many difficulties and much opposition from the native merchants and dealers, bit by bit was the business built up, so that at the present moment we have nothing like it in Persia(19)."

It is not possible to cite the whole sentences of Consul General J. R. Preece on the condition of carpet production and trade at Soltanabad here. So would like to sum up its contents based upon his report.

Soltanabad was quite a new town, situated at 20 miles at the south of Farahan. The town was divided into mahallehs, some 40 in all. It had 11 masjids, 30 hammams, 1 madraseh, 21 caravansarais, 16 kanats, 8, 000 houses, 35,000 population. The town was assessed at 35,000 tomans taxes annually.

Ziegler \& Co. built large premises just outside the town, covering about 40, 000 square yards, at a cost of some $6,000 l$. . It was so large and imposing that the townspeople gave it the name of the Kal'ah, or the Fort. Here they had the dwelling-houses of their employees, the offices, the store rooms, and the dying rooms.

According to Mr. Alpiger, Ziegler \& Co.'s manager, when he first came to Soltanabad, nearly 20 years ago, he found only about 40 looms. However, in 1893 there were at least 1,200 looms, and in the villages around there were certainly another 1,550 looms. Altogether some 3,000 looms were in work all over this country, involving an annual output of 5,000,000 krans worth of carpets.

It is the peculiarity of Ziegler \& Co.'s carpet production that the company employed women and girls as laborer and made them weave carpets, 1 to every 21 inches based upon a unified standard in a woven factory. The pattern was first designed on sectional paper, and then was given to special men, who work it out. If the design comes out right, and was effective, it was given out to a weaver, and from this single pattern, hundreds of carpets were woven. The wool yarn used for the design came mostly from Vol. XXIX 1993 
Golpayigan. The cotton twist used for the warp was brought from $\mathrm{K}$ ashan(20).

Besides Ziegler \& Co., another foreign firm, Messrs. J. C. P. Hotz and Son which had headquarters at London, Bushehr, and Isfahan, opened another carpet factory, ten years later after the establishment of Ziegler' s factory. Besides these two firms, there were the various woven factories of native dealers and traders, including Jews. But regrettably these production systems are not clear(21).

Anyhow, Soltanabad enjoyed an epoch making prosperity by the carpet production. Consul General J. R. Preece explained as follows.

"In no town of Persia have I seen such evidence, not of wealth quite, but of well-doing and well-being. The people are all comfortably dressed and look contended and happy; they all live on the carpet weaving - its good effects are evidenced in the whole community. In my life in Persia, I have seen most of its more important town, but no place impressed me so much as Soltanabad(22)."

\section{III}

The carpet production of Soltanabad developped into a large and flourishing export trade by a strong and growing demand for Iranian carpets in European and American markets. However, in 1890s the supply of carpets could not meet the demand, and then the prices were continuing to show fanatic rises and the quality of carpets considerably deteriorated.

It is of urgent necessity to solve this problem, so both European and Iranian native entrepreneurs earnestly thought to improve the carpet production system centered on Soltanabad and to extend production places from Soltanabad to any other towns and areas. J. R. Preece stated such a situation in his report for $1896-97$ as below.

"As the carpet market at home, in France and America is now very active, and Persian carpets are much in demand, I hope to see this trade more fully developped, although Sultanabad is now practically worked up to its utmost capacity, and the output from there is nearly if not quite at the highest level it can reach; but there are other points which can be exploited, and a trade worked up equal to Sultanabad, viz., in the neighbouring district of Burugird, and also in Kerman; as regards the capabilities of this latter place I have dealt with them fully in a previous report." 
I see that lately a Persian carpet manufacturing company has been started in London. It is to be hoped that they will direct some of their energies towards these places, and not try to force the trade in Sultanabad alone, which will eventually result in heightening of prices or else in reduction of quality in the making of the carpets, either leading to deterioration of the general output(23)."

In 1890s two major production centres for carpet were rising in Iran. One is Tabriz, another Kerman. The entrepreneurs of these cities were mainly native merchants and manufacturers, not foreign firms. This is the peculiarity of these cities compared with Soltanabad in production and trade.

Originally Tabriz was known to be the most important trading center for collecting and distributing the carpets all over Iran, but around 1895 this town began to play a leading role even in carpet production.

Consul General C. G. Wood at Tabriz made his remarks about this condition in his report for the years 1898-1899 as below.

"The large demand high prices paid until quite recently for Persian carpets and rugs, tempted the Tabreez people some three years ago to start looms. Gradually this venture, which became a paying one, gained large proportions, and up to the beginning of last year the work was in full swing, there being scarcely a house or shop which had not put up one or two looms, for not only were the manufacturers gaining money, but the poor class and chiefly boys found employment, whilst the distress which had been prevailing here for so long was somewhat relieved by the fact that parents were helped by their offspring to tide over bad times.

The quality of the Tabreez carpet, whether of silk or wool, is decidedly good, but the workmen are not sufficiently experienced to turn out their work as correctly as their fellow craftsmen in Sultanabad, Kerman, Khorasan, or Kurdistan.

The style and quality of the Tabreez manufacture is very similar to that of the Kerman products, which are much appreciated. The main defect of the local article is a slight lack of symmetry. This is a defect which will be remedied in time; and there seems little doubt that Tabreez, when it has gained experience, will become one of the important carpet-manufacturing centres in Persia(24)."

The carpet making in Tabriz was mostly carried on in the weavers' homes, the women and children doing the weaving. Merchants and manuVol. XXIX 1993 
facturers supplied to the weavers the design and the quantities of wool in different colours required for one carpet. They also frequently advanced sums to account of the price arranged, and so the balance was paid on delivery of the finished article. The practice had the usual disadvantages of home employment, slovenly and dilatory work, with little progress towards skill and finish, as the looms, scattered over a wide area, could not be constantly inspected(25).

On the other hand, a few merchants of Tabriz made an investiment to build a small scale woven factory. We can furnish an instance of such manufacturers from the Zendeghāni-ye man written by Aḥmad Kasravi.

Kasravi's father was truely one of such manufacturers in Tabriz. He was born at Hokmāvār district. His family had been molla for generations. But Kasravì's father did not like to be molla, so from early youth onward, he worked to become merchant in bazar.

At the end of the 19th century when the boom of carpet making broke out in Tabriz, he did not miss a good opportunity to establish a carpet factory with his cousin Hājji Mìr Āqā, making their own investment by halves. He employed many orphan boys as weaver in his factory. His attitude toward employees and his management principle was charitable, because he used to offer lunch to employees every day in addition to finishing work one or two hours earlier than at any other factories(26).

Generally carpet factories in Tabriz employed boys of eight to twelve years old as labourer. This is different from the labor condition in factories of Soltanabad, which used to employ women and girls.

Carpets, woven in factories or homes in Tabriz, were exported abroad. They were first brought to Istanbul, and next from there re-exported to Europe and America. The traders of Tabriz considered Istanbul to be the most important wholesale market for Iranian carpets. So the depression in world economy was destined to give great damage to Iranian carpets in Istanbul. According to Kasravī's autobiography, when the depression broke out in 1902, carpets which had been brought from his father's factory continued to be kept at the storehouses in Istanbul about one year without buyers(27).

The expansion in the carpet industry and trade of Tabriz promoted to link the carpet production of Kerman with the international networks of the carpet trade.

J. R. Preece, Consul General of Isfahan, demonstrated in his report for 
the years 1892-93 that the carpet production of Kerman had been very small only for domestic markets, especially Kerman province until the first half of 1890 s, whereas Annette Ittig, Canadian researcher, makes clear in her study on the Kermāni boom of the carpet production that in the second half of 1890s, the explosive growth started.

This is due to the influx of funds from non-Kermāni groups, Azerbaijani merchants into Kerman. Especially the Dilmaghānis, one of the famous Azerbaijani merchant family, made a great deal of capital investment on the Kerman carpet industry. They advanced money to the carpet weavers in Kerman, and so in 1911 at least 2,000 weavers in Kerman were under contract to Dilmaghānis.

The Tabrizi entrepreneurs expanded the carpet industry and re-oriented it from domestic to international markets. In 1904, the trade in Kermāni carpets was a virtual monopoly of the Tabrizis, and Istanbul was the trading centre for re-export of Kerman carpets(28).

\section{IV}

Iranian carpets were exported abroad from three routes, that is, 1) from the ports of Bushehr and Bandar 'Abbas in the Persian Gulf, 2) from Transcaucassian route, and 3 ) from Tabriz-Trabzon route.

However, the percentage of the value of amount in the carpet export trade from the first route was lower than any other routes. Carpets were mostly exported from the second and the third routes.

It can be testfied by Table 4 which Moḥammad 'Ali Jamālzādeh drew up in his Ganj.e Shäyigān. This table shows the statistics of four years alone in the constitutional period of Iran, but we can point out the tendency of the carpet export trade.

According to this table, it is understood that the percentage of direct trade between Iran and America and the United kingdom was very low. The highest one was even $14.9 \%$ in $1910-11$.

Most carpets were exported first to Russia and the Ottoman Empire, and then re-exported to other countries from the main transit ports such as Odessa and Istanbul.

Istanbul played a great role in the international trade networks of carpets. This town collected carpets from Iran, Transcaucasus and Central Vol. XXIX 1993 
Asia in addition to the inner Anatolia such as Kayseri, Sivas, Van, Uşak, Isparta and Burdur. Jamālzādeh stated Istanbul as the center for the wholesale dealing of carpets as follows, "Istanbul has the wholesale market for Iranian carpets in great quantity. Every year, from there Iranian carpets are exported to Europe and America(29)."

Iranian wholesale dealers continued to reside and undertake export trade in Istanbul owing to the commercial importance of the town. In 191415, the city of Istanbul published the figures of wholesale dealers in every type of business and every ethnicity in the 1330 senesi Istanbul Belediyesi Ihsiaiyat mecmuası, Dersaadet, 1331. According to this statistics cited at Table 5, it is understood that Iranian wholesale dealers undertook only jobs of carpet trade and they occupied 33\% of all, exceeding Turkish, Armenian, Greek, Jewish and other traders in number.

Iranian community in Istanbul was comprised almost by Azerbaijani Turks by origin. The Iranian population of Istanbul numbered no more than 16,000 in 1885 based upon Farāhānī's Safarnāmeh-ye Mekkeh. On the other hand, Khān Malek Sāsānī, a diplomat of Iranian Embassy in Istanbul and the afforesaid Farāhāni's son, scrutinized the registered documents of $1888 / 89$ kept at the embassy, and so calculated the Iranian population at 14,000. Of these figures, 10,000 people were estimated to be Azerbaijani Turks.

The Predominance of Azerbaijani Turks in number is due to the nearness of their residing areas to Istanbul, to the similarity of the Azerbaijan language to the Ottoman Turkish and to their skill in trade. Mr. Jones, Consul General at Tabriz, in his report for 1872 wrote down their pecularities and advantage in trade as follows.

"The Persian, like the Arab, is by nature a trader, and from the earliest times this class has been held in high honour in the East, and favoured with many privileges. The shifty and tricky character which the native trader bears seems more characteristic of the Turk of this province (Azerbijan) than of the real Persian(30)."

Also Consul General C. E. Stewart stated in his report dated September 16, 1890 as follows. "It (=Azerbaijan dialect) differs considerably from that spoken by the Turks in Constantinople, as it does also from the Turki spoken in Bokhara and further eastward; but persons speaking the Azarbaijan dialect have this advantage that, as their dialect is an intermediate one 
ISTANBUL AND THE CARPET TRADE OF IRAN IN THE NINETEENTH CENTURY

between the different dialects of Turkish, they can make themselves understood either in Constantinople or Bokhara, which is a great advantage to them as traders and carriers of goods(31)."

The traders of Azerbaijani Turks, whose head quarters were at Tabriz, also made their relatives, agents and correspondents reside in Istanbul. The nucleus of Iranian community in Istanbul was the famous caravansarai Valide Hanı at the back of Kapalı Çarışı. We can enumerate the example of Azerbaijani traders residing there from Persian historical sources.

In 1887, Persian Sūfī, Pìrzādeh had the chance to meet and talk with the families of a Tabrizi merchant residing at Valide Hanı, when he visited Istanbul on his way from Europe. According to Pirzādeh, this family's head was called Hājjī Ja'far Āqā. He had four sons named Hājjī Mīr Qāsem, Hājjī Mīr Moḥammad Āqā, Hājjī Mìr Āqā and Hājjī Mìr Ne'matollāh. They used to go and come back from Tabriz to Istanbul by turns. When Pīrzādeh called at Valide Hanı, he eventually met the second son, Hājjī Mīr Moḥammad $\bar{A} q \bar{a}$. A few days later, he also met the third son, Hājjì Mīr Āqā who came to Istanbul in order to take turns. At the time of Pīrzādeh's stay, this family's head Hājjī Ja'far $\overline{\bar{A}} q \bar{a}$ resided at Valide Hanı only for a short time on his way to and from Mecca, and at that year he passed almost all time at Tabriz(32).

This families dealt in broadcloth, silk fabrics, calicos and chintz, but regrettably we cannot ascertain they dealt in carpets or not. The annual average transaction of this family amounted to 70,000 lira, but in 1887 this family failed to take back the money on credit for 20 months. Therefore, the real transaction lowered to 40,000 lira(33).

Anyhow, Iranian merchants, especially Azerbaijani Turks of Tabriz continued their energetic commercial activities in Istanbul. However, as soon as World War I broke out, the importance of Istanbul as a worldwide carpet market decreased. It is due to the lock-out of the Bosphorus strait and the rise of customs duties imposed on carpets, which had been $7 \%$ before World War I.

Soon after the formation of the Republic of Turkey, Istanbul lost its importance in international carpet trade. According to the economic report of Istanbul Chamber of Commerce (Ticaret ve Sanayi Odasında müteșekkil Ístanbul Íktisad Komisyon tarafindan tanzim olunan Rapor, 29 Kanun-i sani 1340-1924_26 Teșrin-i sani 1340-1924,) İstanbul, 1341, the center for carpet 
trade was transfered to London from Istanbul, and so Iranian and Armenian wholesale dealers in Istanbul migrated to London after World War I(34).

\section{Notes}

$\begin{array}{ll}\text { GBPP } & \text { Great Britain Parliamentary Papers } \\ A \& P & \text { Accounts \& Papers } \\ D C R & \text { Diplomatic and Consular Reports } \\ A S & \text { Annual Series }\end{array}$

(1) See Guity Nashat, The Origins of Modern Reform in Iran, 1870-80, University of Illinois Press, 1982.

(2) See Feridūn Ādamiyat, Andīshehhā-ye Āqākhän Kermānī, Tehran, 1357.

(3) See Zendegī-ye Tūfānī (Khāterāt-e Seyyid Hasan Taqĩzādeh), Beh Kūshesh-e İrāj Afshār, Tehran, n. d. ; Yahyā Doulatābādi, Hayãt-e Yahyā, 4 Jeld, Tehran, Chap-e sevvom, $1341 \mathrm{SH}$.

(4) Jacob M. Landau, The Politics of Pan-Islam, Clarendon press, Oxford, 1990, pp. 31-32; Abu al-Hasan Mirzā Qājār (Shaykh al-Raìs), Ettehäd-e Eslām, Beh Kūshesh -e Sādeq Sajjādi, 1343SH.

(5) Mirzā Moḥammad Ḥoseyn Farāhāni, Safarnāmeh, Beh Kūshesh-e Ḥāfez Farmān Farmā'yān, Tehran, 1342/1964, pp. 136-44.

(6) Tsutomu Sakamoto, "Armenian Traders and their Commercial Urban Networks in the Modern Islamic World," in Papers on the research project "Urbanism in Islam," Tokyo, 1991 (in Japanese), pp. 352-60.

(7) Charles Issawi, The Economic History of Iran 1800-1914, The University of Chicago Press, 1971, pp. 247-49.

(8) Charles Issawi, "The Tabriz-Trabzon Trade, 1830-1900: Rise and Decline of a Trade Route," IJMES, I (1970), pp. 18-27.

(9) Charles Issawi, The Economic History of Iran 1800-1914, The University of Chicago Press, 1971, p. 143.

(10) Ibid., pp. 103-8.

(11) "Report by Consul Churchill on the Silkworm Disease in Ghilan," GBPP 1876, LX XIV, A \& P 33, PP. 69-70.

(12) "Report by Consul General Abott on the Trade and Commerce of Tabreez for the year 1877-8," GBPP 1878, LXXV, A \& P 30, p. 1696.

(13) "Report by Consul-General Jones on the state of Trade in the province of Azerbaijan during the Year 1872," GBPP 1873, LXV, A \& P 27, p. 968.

(14) Ibid., p. 969.

(15) "Report by Consul-General Abott on the Trade and Commerce of the Province of Azerbaijan for the Year 1878-79," GBPP 1880, LXIII \& P 34. p. 114.

(16) D. Wright, The English amongst the Persians during the Qajar Period 17871921, London, 1977, p. 99.

(17) do.

(18) Professor John Gurney kindly pointed out to me that Annette Ittig had already done research in the carpet production of Ziegler \& Co. using private documents written by Mr. Alpiger. Her research was submitted to Oxford University as $\mathrm{Ph}$. D thesis.

ORIENT 
(19) "Report for the Years 1892-93 and 1893-94 on the Trade \& c., of the Consular District of Ispahan," (Report of a Journey made to Yazd, Kerman, and Shiraz, and on the Trade \&c., of the Consular District of Ispahan, by J. R. Preece," GBPP 1894, LXXXVII, $A \& P$ 37, DCR - AS 1376, p. 56.

(20) Ibid., p. 54, pp. 56-59.

(21) Ibid., p. 58.

(22) Ibid., p. 57.

(23) "Report on the Trade and Commerce of the Consular District of Ispahan for the Year 1896, by Preece," GBPP 1897, XCII, $A \& P$ 41, DCR - AS 1953, p. 6 .

(24) "Report for the year 1898-99 on the Trade and Commerce of Azerbaijan," GBPP $1899 C I, A \& P$ 51, DCR 2291, p. 8.

(25) "Report on the Condition and Prospects of British Trade in Persia by H. W. Maclean, special Commissioner of the Commercial Intelligence Commitee of the Board of Trade," GBPP 1904, XCV, $A \& P, 47$, p. 33.

(26) Aḥmad Kasravi, Zendegäni-ye Man, Tehrān, 1323A.SH. pp. 5, 17, 19-20.

(27) Ibid., p. 20.

(28) Annette Ittig, "The Kirmani Boom-A Study in Carpet Entrepreneurship," in Robert Pinner \& Walter B. Denny (ed.), Oriental Carpet \& Textile Studies I, London, 1985, pp. 111-123.

(29) Seyyid Moḥammad 'Ali Jamālzadeh, Ganj-i Shāyigān, Tehrān, 1362A.SH, p. 21.

(30) “Tabreez: Report by Consul General Jones," GBPP 1873 LXVII, p. 377-78.

(31) "Report on the Trade of North-Western Persia for the Year ending March 21, 1890, by Consul-General C. E. Stewart," GBPP 1890-91, LXXXVII, A \& P 40, DCR AS 798, p. 2.

(32) Safarnāmeh-ye Hājjī Pìrzädeh, Beh Kūshesh-e Ḥāfez Farmān Farmā'yān, Tehran, 1342-43SH, Jeld-e dovvom, pp. 86-87.

(33) Ibid., p. 88

(34) Ticaret ve Sanayi Odasında müteșekkil İstanbul İktisad Komisyonu tarafından tanzim olunan Rapor, 29 Kanun-i sani 1340-1924—26 Teșrin-i sani 1340-1924, İstanbul, 1341 , s. $29-32$. 
Table 1 Source: Tabreez: Report by Consul Jones, GBPP 1873 LXVII, p. 3

\begin{tabular}{|c|c|c|c|c|c|c|}
\hline Year & $\begin{array}{c}\text { Total } \\
\text { Imports } \\
£\end{array}$ & $\begin{array}{c}\text { Of British } \\
\text { Manufactures } \\
£\end{array}$ & $\left|\begin{array}{c}\text { Total } \\
\text { Exports } \\
\mathcal{L}\end{array}\right|$ & $\begin{array}{c}\text { Of Silk } \\
£\end{array}$ & $\begin{array}{l}\text { Total Exports/ } \\
\text { Total Imports } \\
\%\end{array}$ & $\begin{array}{l}\text { Silk Export/ } \\
\text { Total Exports } \\
\%\end{array}$ \\
\hline 1837 & 985,000 & 600,000 & 105,000 & $?$ & $10.7 \%$ & $?$ \\
\hline 1839 & 591,825 & 450,000 & 464,219 & 214,180 & 78.4 & 46.1 \\
\hline 1844 & 703,204 & 562,000 & 369,057 & 131,418 & 52.5 & 35.6 \\
\hline 1848 & 830,773 & 771,943 & 343,738 & 144,030 & 1.4 & 41.9 \\
\hline 1850 & 882,175 & 762,003 & 607,128 & 236,434 & 68.8 & 38.9 \\
\hline 1858 & $1,639,225$ & $1,368,300$ & 974,942 & 389,300 & 59.5 & 39.9 \\
\hline 1859 & $1,786,488$ & $1,518,207$ & 965,140 & 409,582 & 54.0 & 42.4 \\
\hline 1863 & $1,460,000$ & 815,000 & 534,000 & 351,000 & 36.6 & 65.7 \\
\hline 1864 & $1,800,000$ & $1,575,000$ & 600,000 & $\underline{502,000}$ & 33.3 & 83.7 \\
\hline 1865 & $1,669,231$ & $1,242,516$ & 886,883 & 499,322 & 53.1 & 56.3 \\
\hline 1866 & $1,699,712$ & $1,107,441$ & 516,626 & 374,400 & 30.4 & 72.5 \\
\hline 1867 & $1,432,069$ & 946,672 & 643,093 & 65,000 & 44.9 & 10.1 \\
\hline 1868 & $1,351,005$ & $1,017,285$ & 683,885 & 80,000 & 50.6 & 11.7 \\
\hline 1869 & $1,575,776$ & $1,123,221$ & 901,218 & 136,400 & 57.2 & 15.1 \\
\hline 1870 & $1,094,717$ & 864,000 & 422,632 & 116,000 & 38.6 & 27.4 \\
\hline 1871 & 789,559 & 611,280 & 340,790 & 119,440 & 43.2 & 35.0 \\
\hline
\end{tabular}


ISTANBUL AND THE CARPET TRADE OF IRAN IN THE NINETEENTH CENTURY

Table 2 Source: GBPP 1875, LXXV, A \& P 34 "Report by Consul General Jones on the Trade and Commerce of Tabreez for the Year 1873" (March 31, 1874), p. 205.

\begin{tabular}{|c|c|c|c|c|}
\hline Articles & $\begin{array}{c}1871 \\
£\end{array}$ & $\begin{array}{c}1872 \\
£\end{array}$ & $\begin{array}{c}1873 \\
£\end{array}$ & Remarks \\
\hline Silk & 119,440 & 140,000 & 91,168 & $\begin{array}{l}\text { Small quantity sent to Marseilles; } \\
\text { market heavy }\end{array}$ \\
\hline Frisons & ......... & 2,000 & 538 & Sent chiefly to England. \\
\hline $\begin{array}{l}\text { Textile } \\
\text { fabrics : } \\
\text { Carpets }\end{array}$ & & 28,000 & 24,576 & Russia, England and Germany. \\
\hline $\begin{array}{l}\text { Colored } \\
\text { cottons }\end{array}$ & 62,928 & 65,000 & 119,440 & Turkey and Southern Russia. \\
\hline Shawls & & 50,000 & 57,600 & $\begin{array}{l}\text { Product of Kerman and Yazd are woven } \\
\text { in the form of scarfs, and used chiefly } \\
\text { for waistbands and coat linings by } \\
\text { Turkey and Georgians. }\end{array}$ \\
\hline Silks & & 14,000 & 5,740 & $\cdots$ \\
\hline Tobacco & 31,466 & 110,000 & 54,444 & $\begin{array}{l}\text { From Shiraz. Exported to Turkey and } \\
\text { Russia. }\end{array}$ \\
\hline Cotton & 29,968 & 5,000 & 1,776 & $\begin{array}{l}\text { Poor and short staple is purchased for } \\
\text { Russia. }\end{array}$ \\
\hline $\begin{array}{l}\text { Wooden } \\
\text { wares, } \\
\text { planks }\end{array}$ & 28,680 & $\ldots . .$. & $\ldots . .$. & \\
\hline $\begin{array}{l}\text { Drugs } \\
\text { and Dyes }\end{array}$ & 20,384 & 17,300 & 29,427 & Sent chiefly to Russia and Turkey. \\
\hline $\begin{array}{l}\text { Dried } \\
\text { fruits }\end{array}$ & 13,668 & 45,000 & 28,644 & Sent chiefly to Russia and Turkey. \\
\hline $\begin{array}{l}\text { Furs, } \\
\text { Lamb and } \\
\text { sheep- } \\
\text { skins } \\
\end{array}$ & 7,504 & 90,000 & 21,224 & $\begin{array}{l}\text { Sent chiefly to Russia, Turkey and } \\
\text { Germany. }\end{array}$ \\
\hline $\begin{array}{l}\text { Leather } \\
\text { and hides }\end{array}$ & 5,552 & 2,500 & 30,272 & $\begin{array}{l}\text { Sent chiefly to Russia, Turkey and } \\
\text { Germany. }\end{array}$ \\
\hline Wax & 1,200 & 1,200 & 1,378 & To Russia and Turkey. \\
\hline Wool & $\ldots \ldots$ & 4,000 & 4,256 & $\begin{array}{l}\text { To Western Europe : some few samples } \\
\text { to Liverpool. }\end{array}$ \\
\hline Various & 20,000 & 30,000 & 13,552 & $\begin{array}{l}\text { Chiefly horses and cattle sold by the } \\
\text { wandering tribes on the frontier. }\end{array}$ \\
\hline Total & 340,790 & 634,000 & 530,997 & \\
\hline
\end{tabular}


Table 3 Exports of Tabriz 1878

Source: GBPP 1880, LXIII, A \& P 34, "Report by Consul-General Abbott on the Trade and Commerce of the Province of Azerbaijan for the Year 1878-79," p. 116.

\begin{tabular}{|c|c|c|}
\hline Articles & $£$ & Remarks \\
\hline Carpets & 65,000 & $\begin{array}{l}\text { To England, France, Germany, Russia, United } \\
\text { States. }\end{array}$ \\
\hline $\begin{array}{l}\text { Cotton cloths, } \\
\text { printed }\end{array}$ & 55,100 & $\begin{array}{l}\text { Manchester cloth, printed with Persian designs } \\
\text { for Georgian markets. }\end{array}$ \\
\hline Silk, raw & 40,000 & Small quantities to Marseilles. \\
\hline Shawls & 32,500 & $\begin{array}{l}\text { Of Kerman and Yazd. Sent chiefly to Turkey } \\
\text { and the Caucasus. }\end{array}$ \\
\hline Tobacco & 28,085 & Of Shiraz. To Turkey and Russia. \\
\hline Dried fruits & 27,500 & To Russia and Turkey. \\
\hline Drugs and spices & 20,000 & To Russia and Turkey. \\
\hline Wool & 7,430 & To Western Europe. \\
\hline Silk wares & 5,200 & $\begin{array}{l}\text { Of Kerman and Yazd. Sent chiefly to Turkey } \\
\text { and the Caucasus. }\end{array}$ \\
\hline Furs & 4,880 & $\begin{array}{l}\text { Fox, lamb, and sheep skins. To Russia and } \\
\text { Germany. }\end{array}$ \\
\hline Wax & 4,690 & To Turkey and Russia. \\
\hline Dyes & 1,912 & To Turkey and Russia. \\
\hline Cotton, raw & 1,500 & Poor and short staple. Finds a market in Russia. \\
\hline $\begin{array}{l}\text { Leather and } \\
\text { hides }\end{array}$ & 1,200 & To Russia Germany. \\
\hline Various & 3,200 & \\
\hline Total & 298,197 & \\
\hline
\end{tabular}


ISTANBUL AND THE CARPET TRADE OF IRAN IN THE NINETEENTH CENTURY

Table 4 Carpet Exports of Iran

Source: Moḥammad 'Alī Jamālzādeh, Ganj-e Shāyigān, Tehran, 1362SH., p. 20.

\begin{tabular}{|c|c|r|r|r|r|}
\hline Year & Exports & to Russia & to Turkey & to America & to U. K. \\
\hline $1907-08(1325-26$ A. SH) & $29,283,911$ & $\begin{array}{r}6,948,632 \\
(23.7 \%)\end{array}$ & $19,893,913$ \\
$(67.9 \%)$ & - & $\begin{array}{r}360,410 \\
(1.2 \%)\end{array}$ \\
\hline $1908-09(1326-27)$ & $39,498,837$ & $\begin{array}{r}8,502,910 \\
(46.8 \%)\end{array}$ & $\begin{array}{r}19,463,826 \\
(49.3 \%)\end{array}$ & $\begin{array}{r}493,690 \\
(1.2 \%)\end{array}$ & $\begin{array}{r}674,394 \\
(1.7 \%)\end{array}$ \\
\hline $1909-10(1327-28)$ & $48,416,559$ & $20,901,980$ & $22,360,623$ \\
$(43.4 \%)$ & $(46.2 \%)$ & $\begin{array}{r}2,136,022 \\
(4.4 \%)\end{array}$ & $\begin{array}{r}4,633,346 \\
(9.6 \%)\end{array}$ \\
\hline $1910-11(1328-29)$ & $45,138,356$ & $\begin{array}{r}19,128,276 \\
(42.4 \%)\end{array}$ & $\begin{array}{r}18,027,765 \\
(39.9 \%)\end{array}$ & $\begin{array}{r}4,633,346 \\
(10.3 \%)\end{array}$ & $\begin{array}{r}2,081,470 \\
(4.6 \%)\end{array}$ \\
\hline
\end{tabular}


Table 5 Wholesale dealers in Istanbul

Source: 1330 senesi İstanbul Belediyesi İhsiaiyat mecmuası, Dersaadet, 1331.

$\mathrm{T}:$ Türk = Turk
$\mathrm{I}:$ Iranlı = Iranian
$\mathrm{M}:$ Musevi $=$ Jewish
$\mathrm{E}:$ Ermeni $=$ Armenian
$\mathrm{R}:$ Rum $=$ Greek
$\mathrm{Y}:$ Yabancı $=$ Foreigner

\begin{tabular}{|c|c|c|c|c|c|c|c|c|}
\hline Type of business & (English) & $\mathrm{T}$ & I & M & $\mathrm{E}$ & $\mathrm{R}$ & $\mathrm{Y}$ & $\overline{\text { Total }}$ \\
\hline elbise maǧazaleri & clothes firms & 18 & 0 & 19 & 23 & 54 & 5 & 163 \\
\hline moda ve mensucat & textiles & 78 & 0 & 27 & 30 & 46 & 11 & 192 \\
\hline tuhafiye & accessories & 60 & 0 & 72 & 144 & 114 & 8 & 398 \\
\hline $\begin{array}{l}\text { kristal-i cam ve } \\
\text { ayna }\end{array}$ & crystal and mirror & 11 & 0 & 28 & 1 & 12 & 6 & 58 \\
\hline $\begin{array}{l}\text { mobilya ve } \\
\text { mefurușat }\end{array}$ & furniture & 155 & 0 & 3 & 8 & 19 & 3 & 188 \\
\hline $\begin{array}{l}\text { kereste ve malzeme-i } \\
\text { inșaiye }\end{array}$ & $\begin{array}{l}\text { timber and building } \\
\text { materials }\end{array}$ & 36 & 0 & 0 & 24 & 48 & 0 & 108 \\
\hline $\begin{array}{l}\text { attariye, drügist ve } \\
\text { mawad-i kimiviye }\end{array}$ & $\begin{array}{l}\text { perfumer and } \\
\text { druggist }\end{array}$ & 112 & 0 & 8 & 18 & 53 & 6 & 197 \\
\hline$\underset{\text { ticarethaneleri }}{\text { yağ ve zeitun yă̌ }}$ & $\begin{array}{l}\text { oil and olive } \\
\text { oil firms }\end{array}$ & 29 & 0 & 2 & 1 & 131 & 0 & 164 \\
\hline halı & carpet & 38 & 49 & 11 & 39 & 6 & 4 & 147 \\
\hline deri & leather & 16 & 0 & 2 & 31 & 40 & 3 & 92 \\
\hline hububat & cereal grains & 13 & 0 & 0 & 3 & 34 & 1 & 51 \\
\hline kürk ve kürkçü & fur, furrier & 21 & 0 & 3 & 22 & 12 & 4 & 62 \\
\hline gemi techizatı & ship equipment & 3 & 0 & 0 & 3 & 11 & 1 & 18 \\
\hline tuzlı balık & salted fish & 2 & 0 & 0 & 0 & 31 & 1 & 34 \\
\hline afyon & opium & 2 & 0 & 0 & 0 & 1 & 5 & 8 \\
\hline Total & & 594 & 49 & 175 & 347 & 612 & 48 & 1828 \\
\hline
\end{tabular}

